\title{
Implementation of Islamic Education Curriculum Development in Al-Ulum Islamic School Medan
}

\author{
Widya Ayuningsih ${ }^{1}$, Syafaruddin $^{2}$, Amiruddin $\mathbf{M S}^{2}$ \\ ${ }^{1}$ Magister Program of Islamic Education Departement, Universitas Islam Negeri Sumatera Utara (UINSU), \\ Medan, Indonesia \\ ${ }^{2}$ Islamic Education Departement, Universitas Islam Negeri Sumatera Utara (UINSU), Medan, Indonesia \\ widyaayuningsih154689@gmail.com
}

\begin{abstract}
The objectives of this research are: (1) to find out the planning of developing Islamic education curriculum in Al-Ulum Islamic School Medan, (2) to know the implementation of Islamic Education curriculum development in Al-Ulum Islamic School Medan, and (3) to find out the evaluation of the development of Islamic Education Curriculum in Al-Ulum Islamic School Medan. The approach taken in this study is a qualitative approach. This means that the data collected is not in the form of numbers, but data that comes from interviews, observations of personal documents, notes, memos and other official documents. The results of this study are: (1) planning the development of Islamic Education curriculum in the Al-Ulum Islamic School in Medan carried out through 3 stages: (a) the development of institutionlevel programs, (b) the development of programs for each subject, and (c) the development of teaching programs in the classroom, (2) the implementation of the development of Islamic Education curriculum in Al-Ulum Islamic School Medan carried out through two types of curriculum namely the intracuricular and extracurricular curriculum, and (3) the evaluation of the development of Islamic Education curriculum in Al-Ulum Islamic School Medan namely by holding monthly meetings and also the supervision of teachers. and conduct comparative study activities to other schools in and outside the city.
\end{abstract}

Keywords

curriculum; Islamic education

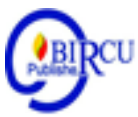

\section{Introduction}

Integrated Islamic schools are essentially schools that implement the concept of Islamic Education based on the Qur'an and Sunnah. In its application an integrated Islamic school is defined as a school that implements an implementation approach by combining public education and Islamic Education into a curriculum. Integrated Islamic schools also emphasize integration in learning methods so as to optimize the cognitive, affective and psychomotor domains. Integrated Islamic schools also integrate aqliyah, ruhiyah and jasadiyah education. In its implementation, it combines the involvement and active participation of the learning environment, namely schools, homes and communities (Fatkuroji published in Nadwa: Journal of Islamic Education, 2012: 250-251).

In the development of the world of education, especially after the rolling reforms, new phenomena have arisen in educational institutions, which are schools that use the term Integrated Islamic Schools (Titik, 2010: 42). The school is essentially aimed at helping parents teach good habits and add good character, also given education for life in society that is difficult given at home. Thus, education in schools is actually part of education in the family, which is also a continuation of education in the family (Daulay, 2014: 75). Integrated Islamic School is a model of new educational institutions in the discourse of 
development of formal educational institutions in Indonesia in the form of discussions about the educational model in Indonesia starting from the establishment of the State of Indonesia to the last in the 20th century (Kurnaengsih, 2015: 78).

The curriculum implemented by the Integrated Islamic school is basically a curriculum adopted from the curriculum of the Ministry of Education and Culture with various modifications. If you look at the curriculum structure of an integrated Islamic school is an integral part of the national education system. Integrated Islamic schools accept all subjects from the national curriculum. Curriculum compiled by the National Education Standards Agency (Mualimin, in the journal Al-Tadzkiyah: Journal of Islamic Education, 2017:105).

The integrated Islamic school curriculum is also part of the educational ideology adopted from the Muslim Brotherhood. This is evident in the ten concepts of musawafat which became the goal in education organized by integrated Islamic schools (Mualimin, in the journal Al-Tadzkiyah: Journal of Islamic Education, 2017: 105). Whereas madrasah is a follow-up of education in pesantren, which teaches $30 \%$ of religious subjects, and the rest are general subjects (Suyatno, 2013: 356). The emergence of integrated Islamic schools was harmonized with the National Education System Law. The law accommodates two formal school models, namely primary and secondary level, which are Islamic or madrasa-based schools and public schools.

Public schools and Madrasas are educational institutions that are formally under the auspices of the National education system. Public schools are under the auspices of the Ministry of Education and Culture. Madrasas are under the auspices of the Ministry of Religion. Whereas pesantren are independent educational institutions which are not under the auspices of the two ministries. The latest development, some pesantren are given equal recognition by the government with these two educational institutions so that pesantren alumni have a diploma that can be used to continue to higher levels in both public schools and madrasas.

The three models of educational institutions above, according to the founders of Integrated Islamic Schools, has failed to realize the ideals of national education. The three educational institutions are not able to produce a generation of believers and who fear God Almighty, noble, healthy, knowledgeable, competent, independent creative and become citizens of a democratic and responsible. Public schools only give birth to alumni who master science and technology but are far from the values of monotheism. Pesantren can only produce alumni who are limited to mastering the religious sciences which are considered insufficient to exist in modern life. Whereas madrasas which originally wanted to bridge the two, up to now have still not been able to give confidence to the community.

Law Number 20 of 2003 which places the position of Islamic Education within the framework of the national education subsystem. Islamic Education has become a compulsory curriculum at every level of education, starting at the elementary, secondary and university levels, both public and private. Therefore to realize the Islamic Education curriculum, it is necessary to implement a maximum Islamic Education curriculum so that the desired learning outcomes can be achieved to the maximum extent possible in accordance with the target.

Curriculum development is a comprehensive term, which includes planning, implementation and evaluation. Curriculum planning is the first step in building a curriculum when curriculum workers make decisions and take action to produce plans that will be used by teachers and students. The application of curriculum or commonly called curriculum implementation seeks to transfer curriculum planning into operational action. Curriculum evaluation is the final stage of curriculum development to determine the extent of learning outcomes, the level of achievement of planned programs and the results of the curriculum itself. Imelda (2019) states that the implementation of the 2013 curriculum refers to a 
scientific approach where learning activities include 5M activities, namely observing, asking, trying, reasoning and communicating. This means that in learning it is hoped that students will be actively involved in the 5M activities. In principle, curriculum development revolves around developing aspects of science and technology that need to be balanced with educational development. Humans, on the other hand, often have limited ability to receive, convey and process information, so a curriculum development process that is accurate and selected is needed and has a strong degree of relevance. In this case, a curriculum development model with an appropriate approach is needed.

The weaknesses in the development of Islamic Education curriculum that occur can be caused by internal and external factors. The internal factors are in the form of Islamic Education curriculum objectives in schools that only prioritize knowing (knowing about the teachings and values of religion) and doing (can practice what is known) and neglecting its being (religious or living life on the basis of teachings and values religious values). The development of Islamic Education curriculum should be more oriented to the level of moral action which includes will and habits, and not just competence. And external factors such as the community environment that is very vulnerable to the growth of aggressive and deviant behavior. For example, the fading of social manners and religious moral ethics in the practice of daily life which is clearly contrary to the teachings of pure religion. Coupled with electronic media shows (for example television) which have also provided their own colors and patterns with a variety of shows that have different characteristics and influence both local and long distance shows.

Therefore, to avoid these weaknesses, it is necessary to develop an actual Islamic Education curriculum, namely the development of an Islamic Education curriculum by replacing it on its philosophical basis, it means that the Islamic Education curriculum should not only be viewed as limited to the content of subjects or lists the subject matter of the Islamic Education curriculum offered to students in completing a learning program in a particular education unit, but has a broader meaning or understanding, namely what is experienced by students or any effort programmed by the school in helping to develop the potential of students through learning experiences that have the potential to achieve the vision, mission, goals, and outcomes desired by the education unit.

\section{Review of Literature}

Etymologically, the term curriculum is derived from Greek, namely curir which means runner, and curere which means "place to race". Thus the term curriculum comes from the world of sports in Ancient Roman times in Greece which contains the understanding of the distance that must be traveled by runners from the start line to the finish line. The term curriculum originally had the meaning of a running corse, or in French that is, "courier" which means "running". The term is then used for a number of "course" subjects that must be taken to achieve an award in the world of education which is often known by the community as a diploma (Abdurrahmansyah, 2008:35).

According to Al-Syaibany quoted from Idi's book, the curriculum in Arabic is translated with the word "Manhaj" which means the bright way, or the bright path that humans walk in various fields of life (Idi, 2007: 184). According to Al-Syaibany, the definition of Manhaj (curriculum) is a narrow and limited understanding, which in the Islamic world continued to run until the mid-19th century. In terminology that is, as a number of knowledge or subjects that must be taken or completed by students to achieve an educational goal or competency set. As a sign or proof that students have reached the competency standard is with a diploma or certificate given to students (Suparlan, 2011: 37). 
Understanding the curriculum according to Law No. 20 of 2003 concerning the National Education System, that the curriculum is a set of plans and arrangements regarding the objectives, content, and learning materials and ways used as guidelines for organizing learning activities to achieve certain educational goals (Suparlan, 2011: 36). Meanwhile Nunan (1988:158) explains the curriculum is the principles and procedures for planning, implementing, evaluating, and managing the design of an educational program.

To give an idea of the complexity of the various definitions, Hasan (1988) put forward the curriculum in four dimensions as follows: First, the curriculum as an idea, that is something that is produced through theoretical studies and research, particularly in the fields of education and curriculum. Second, the curriculum as a written plan, that is, as an embodiment of the curriculum as an idea in which contains the objectives, materials, activities, tools, and time. Third, the curriculum as an activity, which is the implementation of the curriculum as a written plan, for example in the form of learning practices. Fourth, the curriculum as a result, which is a consequence of the curriculum as an activity, in the form of achieving the curriculum goals, or learning objectives, namely achieving behavioral change. learners, or certain abilities of students.

Curriculum development is the process of curriculum planning and preparation by curriculum developers and activities undertaken so that the resulting curriculum can become teaching materials and references used to achieve national education goals. Curriculum development refers to the activities of producing curriculum. Development activities, consisting of activities of drafting, implementing, evaluating, and refining (Pratt in Surahmad, quoted by Nurgiyantoro, 2008). Furthermore Nurgiyantoro (2008:17) argues, that development is an activity to produce something.

Curriculum development is an activity to produce a new curriculum through the steps of curriculum preparation on the basis of the results of the assessment carried out during a certain period, curriculum development means a total change and transition from one curriculum to another, and these changes last for a long time (Soetopo and Soemanto, 1993:45). According to Hamalik (1993: 45), curriculum development is by planning learning opportunities that are intended to foster students or students towards the desired behavioral change and assess the extent to which these changes have occurred in the student concerned.

Furthermore, related to the principles of Islamic Education according to Muhaimin and Majid (1993: 187) the principles of Islamic Education curriculum development are:(1) religious principles, (2) philosophical principles, (3) psychological principles, (4) sociological principles, (5) Organizational principles, and (6) principles of science and technology.

Islamic Education means systematic and pragmatic efforts in helping students to live according to Islamic teachings (Zuhairini., 1983:27). Islamic Sharia will not be internalized and practiced if only taught, but must be educated through the process of education of the prophet in accordance with Islamic teachings with various methods and approaches from one side we see that Islamic education is more aimed at improving mental attitude that will manifest in charitable deeds both for oneself and others' needs. From another aspect, Islamic education is not only theoretical, but also practical.

Islamic teachings do not separate faith and good deeds. Therefore, Islamic education is at the same time faith education and charity education and also because Islamic teachings contain teachings on attitudes and personal behavior of the people towards individual and shared welfare, Islamic education is individual education and community education. Initially in charge of educating were the Prophets and Apostles then the scholars, and cleverly clever as successors to their duties and obligations (Darajat, 1993: 25-28). 
Islamic Education can be defined as an effort to actualize the attributes of perfection that have been bestowed by Allah swt., To humans, these efforts are carried out without any strings attached except to merely worship Allah (Bawani, 1993: 65).

Islamic religious education is a very urgent matter for children, as for the purpose of Islamic religious education is to guide children so that they become true Muslims, firm faith, pious charity and noble character and are useful to society, religion and the State (Wardany, 2019). Lukman (1995: 139) states that Islamic Education is as a process of delivering information in the context of the formation of faithful and pious people so that people are aware of their position, duties and functions in the world by always maintaining their relationship with God, himself, society and the natural surroundings as well as responsibility answer to God Almighty including himself and his environment.

Al-Syaibany argues that Islamic Education is the process of changing the behavior of individual students in their personal lives, society and the natural surroundings. The process is carried out by means of education and teaching as something of human and professional activity among the many human rights professions in society.

Al-Jamaly defines Islamic Education as an effort to develop, encourage and invite students to live more dynamically based on high values and noble life. With this process, students are expected to form more perfect personal, both related to the potential of reason, feelings and actions.

Marimba argues that Islamic Education is guidance or leadership consciously by educators on the physical and spiritual development of students towards the formation of a primary personality (insan kamil). Meanwhile Tafsir (2005: 45) defines Islamic Education as guidance given by someone so that he develops optimally in accordance with Islamic teachings.

The basis or foundation of Islamic Education is the Qur'an and the Hadith of the Prophet. Furthermore, the aim of Islamic education is to prepare children so that when they grow up they will do enough of the work of the world and the practice of the hereafter to create happiness with the worlds (Yunus, 1978:10). Because education is a tool used by humans to maintain their survival, both as individuals and as a society (Langgulung, 1995:147). The purpose of Islamic Education is ubudiyah (worship) servitude to God. This opinion is based on the word of God, meaning: "they were not instructed, but that they worshiped God and gave religion to Him" (Qur'an, Surah Al-Bayyinah Verse 5).

The purpose of education is a very important factor, because it is the direction that education aims to aim at. Likewise, the Islamic Education, which includes subjects of noble morals is intended to shape students into human beings who believe and fear God Almighty and have good morals. Noble characters include ethics, characters, or morals as an embodiment of Islamic Education.

The purpose of education is formally defined as the formulation of qualifications, knowledge, abilities and attitudes that must be possessed by students after completing a lesson in school, because the purpose of functioning is to direct, control and facilitate the evaluation of an activity because of the educational goals are identical to the goals of human life.

The general goal of Islamic Education is to achieve the quality mentioned by the Qur'an and hadith while the function of national education is to develop capabilities and shape the character and civilization of a dignified nation in order to educate the life of the nation, aiming to develop the potential of students to become human beings who believe and be dedicated to God Almighty, noble, healthy, knowledgeable, capable, creative, independent, and become a democratic and responsible citizen. 
According to Jalal the general goal of Islamic Education is the realization of humanity as an addition to God, he said that this goal would realize special goals. By quoting Surat atTakwir verse 27. Jalal states that the goal is for all humans. So according to Islam, education must make all human beings become people who worship themselves to God or in other words of worship of God.

Specific objectives of Islamic Education are goals that are adjusted to the growth and development of children in accordance with the level of education that goes through, so that each goal of Islamic Education at each level of school has different goals. The specific objective of Islamic Education for the Middle School level is to increase intelligence, knowledge, personality, noble character, skills for independent living and to take further education and to improve the procedures for reading the newspaper and recitation to the procedure for applying the law of reading mad and endowments. Familiarize commendable behavior such as qanaah and tasawuh and keep away from despicable behavior such as ananiah, hasad, ghadab and namimah and understand and emulate the mandatory bathing procedures and obligatory prayers and circumcision prayers (Riyanto, 2006: 160).

\section{Research Methods}

This research is a qualitative research with a phenomenological approach that is directed to describe and analyze in depth about the implementation of Islamic Education curriculum development in the Islamic School al-Ulum Medan. Data collection techniques carried out by triangulation techniques (combined), data analysis is inductive/qualitative, and qualitative research results emphasize more on the meaning of generalization (Sugiyono, 2006: 14).

\section{Discussion}

\subsection{Planning Development of Islamic Education Curriculum}

The first finding, curriculum development planning is carried out by forming a curriculum development team at the Al-Ulum Islamic Integrated Middle School. Then prepare the programs to be developed.

Planning the development of Islamic Education curriculum through several stages. The stages of planning the development of Islamic Education curriculum is a curriculum development that is applied in Indonesia. In developing school curriculums in Indonesia, especially those which are goal-oriented, they will go through stages of program development at the institutional level, program development in each subject, and development of teaching programs in schools. (Syaodih, 2002: 150-151).

\section{a. Institutional Level Program Development}

The development of this institution-level program can be seen from various types of religious activities carried out by the Al-Ulum Islamic School Medan such as congregational prayers, duha prayers and the existence of a 3 language speech schedule after duha, reading al matsurat, tahfiz and tahsin Alquran, then there are activities MABIT. MABIT (Night of Faith and Takwa Cultivation) is filled with tahajjud, dhikr, prayer, muhasabah and religious lectures.

This institutional-level program development includes three main activities, namely, the formulation of institutional goals, determination of the contents, and structure of the program, as well as the preparation of the overall curriculum implementation strategy. 
1) Formulation of institutional goals.

Namely the objectives expected to be mastered by school graduates after completing the school. These objectives should include three aspects, aspects of knowledge, attitudes and values, and skills. The sources that can be used to determine the formulation of institutional objectives are; national education goals, community expectations, higher school expectations. Institutional goals can be categorized into general goals and special goals. General institutional goals are goals that are generally expected to be owned by children after completing education in a school. Whereas special goals are goals that are specifically expected to be owned by school graduates. This specific objective is a general purpose description. The formulation of specific objectives usually includes three aspects, namely aspects of knowledge, attitudes and values, and skills.

2) Determination of program content and structure.

After the formulation of institutional objectives has been formulated, the next step is to determine the contents and structure of the program. Determination of program content in the form of determining subjects that can sustain the achievement of educational goals. Determination of the structure of the program includes the determination of the following matters: first, the determination of the types of programs to be held at a school, for example general education programs, academics, specialties and others. Second, the determination of the organization or form of preparation of learning materials in the curriculum, for example the preparation in the form of separate subjects (subject-matter) or in the form of interrelated subjects (correlated). Third, determining the unit of time used, for example by the quarterly or semester chess system, the number of subjects, and the number of hours of study a week and day.

3) Compilation of curriculum implementation strategies.

Curriculum implementation strategies are related to curriculum implementation in schools. Included in the curriculum implementation strategy, for example the implementation of teaching in the form of lesson packages, implementation of teaching with modules, complete learning strategies, teaching with a credit system, intracuricular activities, learning with a process skills approach, strategies for implementing student learning outcomes assessment, implementation of guidance and counseling, administration, educational supervision, and including the methods and media used in teaching.

\section{b. Program Development for Each Subject}

Sudja'i, (2013: 135-138) said that the program development steps for each subject (field of study) included several activities, namely:

1) Formulate Curricular Objectives.

Formulation of curricular objectives must be based on institutional goals. Because cumulative curricular goals are institutional goals themselves. In curricular objectives, goals are formulated that include aspects of knowledge, skills, and attitudes and values that are expected of students in each subject.

2) Formulating instructional objectives.

What is meant by the formulation of instructional objectives here is general instructional objectives. These are the educational goals that students expect to have for each subject. These instructional objectives are spelled out directly from curricular goals. Therefore a curricular goal can have one or several instructional goals. This cumulative achievement of instructional goals will realize the achievement of curricular goals. Compared with the curricular goals these instructional objectives are more specific, operational, can describe the behavior of student learning outcomes can be measured. 
3) Establishing subjects and sub-subjects.

After completing the formulation of curricular goals and instructional objectives the next step is to set the subject. Because the subjects must be based on instructional objectives. After setting out the main points the teaching material is prepared. One instructional objective can be translated into a number of descriptions of teaching materials. Thus there is a close relationship between curricular goals, instructional objectives, subject matter and description of teaching material.

4) Develop a learning program plan.

The next step is to prepare a learning program plan. Based on this learning implementation plan the teacher carries out teaching activities and textbooks are prepared. Based on this learning implementation plan, it is expected that each school will have the same direction, which is directed to achieve national goals. The components of Islamic Education include; formulation of core competencies and basic competencies, learning indicators, subject areas, and description of teaching materials. The components are arranged systematically according to semester and class. Within one semester, for each subject included one basic competency, several learning indicators, and a description of teaching materials. In addition to these components, the number of study hours included in each time, the learning methods used, the means or source of learning materials, assessment techniques and additional information. The way to develop a lesson plan is that all components are arranged in parallel from left to right, starting from the curricular objectives to the assessment techniques. If the preparation of the learning implementation plan is completed, then complete the task of the national team in an effort to develop the school curriculum. The next task is the task of fostering the curriculum: supervision, monitoring, and assessment of the implementation of the curriculum in the field.

\section{c. Development of Classroom Teaching Programs}

Making unit lessons is curriculum development activities in the form of classroom teaching programs. This activity is carried out by each teacher. The unit of study consists of: (1) general instructional objectives taken from the learning implementation plan, (2) learning indicators, (3) a description of the lesson material that is directly translated from the description of the material in the learning implementation plan that bases itself on the learning indicators that have been formulated. The following components are (4) planning of teaching and learning activities, (5) choosing the methods, tools, or media used, as well as material sources, and (6) evaluating both the procedure and the assessment tool itself. Every teacher who will conduct teaching and learning activities in class is required to arrange unit lessons. This learning unit, among others, functions to limit and direct all activities of the teacher so that it always runs on the objectives of the lesson to be achieved.

\subsection{Implementation of Islamic Education Curriculum Development}

The second finding, the implementation of Islamic Education curriculum development was carried out inside and outside the classroom in the form of intracuricular activities in Islamic Education curriculum and also extracurricular activities in Islamic Education curriculum. So that was applied in the Al-Ulum Islamic School Medan. In the Islamic Education, education extracurricular curriculum activities were divided into five activities such as daily activities, Weekly activities, Monthly Activities, and Annual Activities. The following explanation is related to the intracuricular and extracurricular activities of the Islamic Education Curriculum. 


\section{a. Intracurricular Activities of Islamic Education Curriculum}

The intracuricular activities of the Islamic Education curriculum are the learning processes carried out in schools during scheduled and structured lesson hours whose time has been determined in the syllabus.

\section{b. Extracurricular Activities of Islamic Education Curriculum}

The extracurricular activities of Islamic Education curriculum are learning activities that are held outside of class hours which are adjusted to the needs of knowledge, development, guidance and habituation of students so that they have basic supporting abilities. As for the outline planning of Islamic Education extracurricular activities carried out at the Al-Ulum Islamic School Medan can be divided into five activities namely as follows:

1) Daily activities.

Daily activities include: Praying at the beginning and end of the lesson, Tahsin Alquran at 7:25 a.m. - 8:00 a.m., Prayers in Prayer, Prayers at Duha, Speeches 3 languages at Duha.

2) Weekly Activities.

Weekly activities include: Recitation of al-Ma'tsurat, Friday Prayers, Mentoring activities. Infaq and Sadaqoh.

3) Monthly Activities.

MABIT Monthly Activities (Bina Iman and Takwa Night). Mutual cooperation to clean the mosque.

4) Annual Activities.

Annual activities include: commemoration of Isra Miraj, commemoration of the Quran nuzulul, Tabligh Akbar, study tour, comparative study, commemoration of the birthday of the Prophet Muhammad SAW, lightning boarding school, Hajj Manasik.

5) Incidental Activities.

Incidental activities include: takziyah, visiting sick people and others.

\subsection{Evaluation of Islamic Education Curriculum Development}

The third finding, with the evaluation of the curriculum can be seen how far the optimization of the objectives to be achieved so that feedback can be obtained about the curriculum and its implementation in learning. Based on this feedback, improvements can be made to the aspects that are not quite right and development to aspects that are already good. Thus the curriculum evaluation is carried out to achieve a goal including:

a. Knowing the weaknesses of the implementation of the curriculum that has been applied, which is then carried out development (improvement) so that educational goals that have been applied can be achieved.

b. Obtain information about the implementation of the curriculum in schools, where the information will be useful as a basis for consideration for decision makers to solve problems encountered in implementing the curriculum.

c. To obtain answers to the completeness of curriculum components in schools, the effectiveness of the implementation of the curriculum, the effectiveness of the use of supporting facilities, the level of achievement of learning outcomes is reviewed in accordance with the objectives and impact of the implementation of the curriculum, both positive or negative. (Raharjo, 2012: 131).

Evaluation of the development of the PAI curriculum conducted by the Al-Ulum Islamic School Medan, namely by holding monthly meetings and also the supervision of teachers. Not only that the principal also routinely conducts comparative study activities to other schools. Not only in the city but outside the city. This is done as an effort to improve the quality of education at the Al-Ulum Islamic SchoolMedan. 
The implementation of curriculum evaluation rests on several planned assumptions, namely:

a. The evaluation program is designed as well as possible in order to obtain good information too.

b. Evaluation programs are limited to findings supported by quantitative data, although they cannot ignore qualitative information.

c. Information obtained through evaluation should be an effective and efficient tool in order to improve and improve instructional quality for students.

d. The curriculum evaluation program is carried out on an ongoing basis and involves evaluating the input components, processes and products because each goal formulation must always be accompanied by instructional evaluation planning. (Hamalik.1993: 6)

Based on the explanation above, it can be understood that evaluation in curriculum development aims to:

a. Program improvement, in this case the role of curriculum evaluation is more constructive, because the evaluation results are used as input for the improvements needed in the curriculum program that is being developed. With the evaluation it will be possible to achieve optimal development results from the system concerned. Accountability to various parties. During and especially at the end of the curriculum development phase, there needs to be some kind of accountability from the curriculum developer to various interested parties. The parties concerned include the government, community, parents, education officials and other parties who have contributed to sponsor the curriculum development activities concerned.

b. In accounting for the curriculum results that have been achieved, the curriculum developer needs to develop strengths and weaknesses of the curriculum being developed as well as the effort needed to overcome weaknesses, to find out the strengths and weaknesses that evaluation is needed.

c. Determination of the follow up to the results of the development which can take the form of answers to two possible questions, first; whether the new curriculum will or will not be disseminated into the existing system? Second; under what conditions and in what ways will the new curriculum be disseminated into the existing system?

\section{Conclusion}

Based on the results of research and discussion that has been described in the previous chapter, conclusions can be drawn as follows:

1. Planning for the development of Islamic Education curriculum are carried out through 3 stages: (a) the development of institutional level programs, (b) the development of programs for each subject, and (c) the development of class teaching programs.

2. The implementation of the development Islamic Education curriculum in is carried out through two activities, namely: (b) the intracuricular activities of the Islamic Education curriculum is a learning process carried out at the school during scheduled and structured lesson hours, which time has passed determined in the syllabus, (b) extracurricular activities of the IslamicEducation curriculum are learning activities that are held outside of class hours that are tailored to the needs of knowledge, development, guidance and habituation of students so that they have basic supporting abilities.

3. Evaluation of the development of Islamic Education curriculum by holding monthly meetings and also teacher supervision. Not only that the principal also routinely conducts comparative study activities to other schools. Not only in the city but outside the city. This 
was done as an effort to improve the quality of education at the Al-Ulum Islamic School Medan.

Recommendations that can be given are as follows: (1) school principals should do the following: (a) involve the entire school community in the curriculum development process, (b) evaluate by monitoring teaching and learning activities with the aim of being able to know the success of teachers in carrying out the task of delivering information to children, and (c) conduct evaluations of learning for teachers, at least once a week. Because the implementation of the curriculum depends on the teacher, and (2) the teacher should do the following: (a) always play an active role in every process of developing the curriculum, (b) carry out the duties and obligations properly, so that the implementation of the curriculum can run according to planned, and (c) sharpening creativity in teaching so that the learning process in more innovative.

\section{References}

Abdurrahmansyah. (2008). Teori Pengembangan Kurikulum dan Aplikasi Telaah Kurikulum PAI di SLTP \& SLTA. Palembang: Grafika Telindo.

Ananda, Rusydi. (2019). Perencanaan Pembelajaran. Medan: LPPPI.

Armai, Arief. (2002). Pengantar Ilmu dan Metodologi Islam, Jakarta: Ciputat Pers.

Daradjat, Zakiah. (1993). Ilmu Jiwa Agama. Jakarta: Bulan Bintang.

Fatkuroji. (2012). Nadwa: Jurnal Pendidikan Islam, Vol. 6, Nomor 2, Oktober 2012 ISSN 1979-1739.

Fuad, Ihsan. (2005). Dasar-Dasar Kependidikan. Jakarta: Rineka Cipta.

Hamalik, Oemar. (1992). Administrasi dan Supervisi Pengembangan Kurikulum. Bandung: Mandar Maju.

Hamalik, Oemar. (2005). Proses Belajar Mengajar. Jakarta: Bumi Aksara.

Hamalik, Oemar. (1993). Sistem dan Prosedur Pengembangan Kurikulum Lembaga Pendidikan dan Pelatihan. Bandung: Trigendi Karya.

Idi, Abdullah. (2007). Pengembangan Kurikulum Teori dan Praktik. Yogyakarta: Ar-Ruzz Media.

Imam, Bawani. Tradisionalisme Dalam Pendidikan Islam. Surabaya: Al-Ikhlas, 1993.

Imelda, and Anzelina, D. (2019). Students' Activities in Learning with Problem Based Learning Based Module to Enhance Students' HOTS on the Subject of Straight Line Equations. Budapest International Research and Critics in Linguistics and Education (BirLE) Journal, 2(4); 552-559.

Irsad, Muhammad. Pengembangan Kurikulum Pendidikan Agama Islam Di Madrasah (Studi Atas Pemikiran Muhaimin. Iqra', Vol. 2, No. 1, November 2016 ISSN: 2527-4449.

Kurnaengsih. (2016). Konsep Sekolah Islam Terpadu (Kajian Pengembangan Lembaga Pendidikan Islam di Indonesia. Jurnal Risalah, Vo. 1, No.1, Desember 2015.loka karya PAI di Garut.

Langgulung, Hasan. (1995). Manusia dan Pendidikan Suatu Analisa Psikologi Dan Pendidikan. Jakarta: Al Husna zikra.

M, Amin. Pendidikan Karakter Anak Bangsa. Jakarta: Baduose Media, 1975.

Maksudin, (2010). Pendidikan Islam Alternatif-Membangun Karakter melalui Sistem Boarding School. Yogyakarta: UNY Press.

Mualimin, Al-Tadzkiyah:Jurnal Pendidikan Islam: Lembaga Pendidikan Islam Terpadu, Volume 8, No I 2017 P. ISSN: 20869118 E-ISSN: 2528-2476.

Nizar, Samsul dan Halim, Abdul, (2002). Filsafat Pendidikan Islam; Pendekatan Historis, Teoritis dan Praktis. Jakarta: Ciputat Pers. 
Sudja'i, Achmad. Pengembangan Kurikulum. Semarang: Akfi Media, 2013.

Sugiana, Aset. Pengembangan Kurikulum Pendidikan Agama Islam Dan Implementasinya di MTs. Nurul Ummah Yogyakarta, Jurnal Pendidikan Agama Islam, Vol. XVI, No.1, Juni 2019.

Suparlan. Tanya Jawab Pengembangan Kurikulum dan Materi Pembelajaran. Jakarta: Bumi Aksara, 2011.

Suyatno. Sekolah Islam Terpadu; Filsafat, Ideologi, dan Tren Baru Pendidikan Islam di Indonesia, Jurnal Pendidikan Islam, Vol. II, No. 2, Desember 2013/1435.

Tedi, Priatna. Reaktualisasi Paradigma Pendidikan Islam. Bandung: Pustaka Bani Quraisy, 2004.

Wardany, D.K. (2019). The Effect of Islamic Education Subject on the Development of Student Social Behavior. Budapest International Research and Critics in Linguistics and Education (BirLE) Journal, 2(2); 92-99.

Yunus, Mahmud. Pendidikan Dan Pengajaran. Jakarta: Hidakarya Agung,1978.

Zuhairini et al. Metode Khusus Pendidikan Agama. Surabaya: Usaha Nasional, 1983.

Zuhri. Convergentive Design: Kurikulum Pendidikan Pesanren Konsepsi dan Aplikasinya. Yogyakarta: Depublish, 2012. 